\title{
FISH ASSEMBLAGE IN A TEMPERATE ESTUARY ON THE URUGUAYAN COAST: SEASONAL VARIATION AND ENVIRONMENTAL INFLUENCE
}

\author{
Alicia Acuña Plavan ${ }^{I}$, Cecilia Passadore ${ }^{1}$ and Luis Gimenez ${ }^{2}$ \\ ${ }^{1}$ Universidad de la República, Facultad de Ciencias, Sección Oceanología \\ (Iguá 4225 CP 11400 Montevideo, Uruguay) \\ ${ }^{2}$ School of Ocean Sciences, University of Wales, Bangor Menai Bridge \\ (Anglesey, LL59 5AB United Kingdom) \\ *Corresponding author: alacia@fcien.edu.uy
}

\section{A B S T R A C T}

\begin{abstract}
The seasonal dynamics of the fish community in the Pando estuary on the Uruguayan coast were studied in relation to environmental sampled monthly between May 2002 and June 2003. Individuals collected were identified, and classified into stages (juveniles, adults) and functional groups. Relationships between community dynamics and environmental variables were evaluated using uniand multivariate techniques. Twenty-one species, mostly freshwater stragglers, estuarine and marine migrants were collected. The most abundant species were Micropogonias furnieri, Mugil platanus, Paralichthys orbignyanus and Brevoortia aurea and were represented by juveniles. The community varied seasonally with rapid shifts in spring and autumn associated with changes in temperature and salinity. Significant correlations between abundance and temperature may be related to the timing of life cycle events. In this estuary, the salinity appears to play a key role in the functional structure and in the use of the habitat by juveniles. This is relevant for the definition of estuaries as nursery areas: this definition is context-dependent and is determined by the salinity conditions.
\end{abstract}

\section{RESUMO}

Foi estudado a dinâmica sazonal da comunidade de peixes em relação as variáveis ambientais do estuário Pando, localizado na costa uruguaia. Os peixes foram amostrados mensalmente entre maio de 2002 e junho de 2003. Os indivíduos coletados foram identificados e classificados em estágios (jovens, adultos) e grupos funcionais. Relações entre a dinâmica da comunidade e as variáveis ambientais foram avaliadas utilizando-se técnicas uni- e multivariada. Vinte e uma espécies foram coletadas, principalmente visitantes de água doce, estuarinas e marinhas migratórias, sendo as mais abundantes e representadas por juvenis: Micropogonias furnieri, Mugil platanus, Paralichthys orbignyanus e Brevoortia aurea. A comunidade variou sazonalmente com rápidas mudanças na primavera e no outono, associadas à variações de temperatura e salinidade. Correlações significativas entre abundância e temperatura parecem estar relacionadas com a sincronizaçao de eventos dos ciclos de vida. Neste estuário a salinidade parece desempenhar um papel-chave na estrutura funcional e uso do habitat por juvenis. Este fato é relevante para a definição dos estuários como áreas de criadouro e pela influencia da salinidade sobre o ciclo da ictiofauna local.

Descriptors: Estuary, Fish assemblage, Pando Estuary, Río de la Plata, Annual variation, Environmental variables.

Descritores: Estuário, Assembléia de peixes, Costa uruguaia, Río de la Plata, Variação anual, Variáveis ambientais.

\section{INTRODUCTION}

Estuaries are complex and highly variable environments and often exhibit abrupt changes in salinity, temperature, turbidity and river and tidal currents (WHITFIELD, 1999; VORWERK et al., 2003). Estuarine fish assemblages are adapted to live under such changing conditions; generally, they consist of freshwater fishes that occasionally enter the brackish waters, anadromous and catadromous in transit, exclusively estuarine fish that remain throughout life in the estuary and marine fish that use estuaries as nursery grounds or spawning areas (POTTER; HYNDES, 1999; COSTA et al., 2002). The relationships especially between temperature on a temporal scale and salinity and turbidity on a spatial scale, along with the abundance of different species, are partly the result of seasonal migrations into and out of the estuaries and, for resident species, partly due to recruitment and mortality within the area (MAES et al., 2004; AKIN et al., 2005; SELLESLAGH et al., 
2009). The high ecosystem productivity constitutes important feeding reservoirs, providing suitable food for larvae and juveniles (KJERFVE, 1994; MOYLE; CECH JR, 2004). As a consequence of low predation pressure, estuaries offer refuge and breeding grounds for many fish species both resident and migrant (POTTER; HYNDES, 1994, 1999; LEVINTON, 1995; THIEL; POTTER, 2001; ELLIOTT et al., 2007).

Estuarine ecosystems are essential not only for marine life but also for humans. As many fishes spend most of their life cycle and have migratory routes there, the environmental integrity of in estuarine habitats is threatened by development of urban communities on their shores (BECK et al., 2001; ABLE, 2005; ELLIOT et al., 2007; FRANCO et al., 2008a; SELLESLAGH; AMARA, 2008). Environmental assessment studies have declared the Uruguayan coastal zone an area of high ecological value and biodiversity but subject to the increasingly adverse effects of anthropogenic activities (EcoPLATA, 2000; FREPLATA, 2005). In this coastal area, semi-closed systems such as coastal lagoons and open areas (river and stream mouths) are to be found. These estuarine habitats are connected to the Río de la Plata and the Atlantic Ocean, where southwesterly and southeasterly winds raise the tides and give rise to influxes of brackish water, depending on the location of the saline intrusion limit of the Rio de la Plata, which varies by season (GIMÉNEZ et al., 2005). The Pando stream, which has a basin of 824 $\mathrm{km}^{2}$ and estuarine characteristics at its mouth, is subject to these effects. The Uruguayan coast may be regarded as a significant fish and crustacean nursery area (FREPLATA, 2005; RETTA et al., 2006). In the Rio de la Plata, fishery species (e.g. Micropogonias furnieri, Cynoscion guatucupa, Macrodon ancylodon, Mugil platanus, Urophycis brasiliensis and Brevoortia aurea) have their spawning and breeding area (ACUÑA et al., 1996, 2000; MACCHI et al., 1996, 2003; ACHA et al., 1999; ACHA; MACCHI 2000; VIZZIANO et al., 2001; BRAVERMAN et al., 2009). Juveniles and larvae of, e.g., M. furnieri (whitemouth croaker), a target of Uruguayan fisheries and second in economic importance, find refuge and food in this area, benefiting from the coastal productivity (ACUÑA et al., 1996; JAUREGUIZAR et al., 2003; NORBIS et al., 2006). Despite the role of Uruguayan coastal habitats for fish nurseries, there is little quantified information available for the ichthyofauna of estuaries of the region. Fish community studies were undertaken in estuarine and oceanic coastal areas along the Uruguayan coast by Giménez et al. (2003) during spring 2002 (unpublished data) and Retta et al. (2006). However, no information is available regarding seasonal variations in fish abundance and information as to the relationships between fish assemblage variation and abiotic conditions is limited. Long periods of extreme salinities could lead to high osmotic stress and trigger the migration of fishes from these estuary systems. In the Pando estuary, salinity can be affected by both local and regional sources. If low salinities reduced the use of these habitats by fish communities, then the estuaries would not function permanently as juvenile habitats or nursery areas. Peaks of abundance can be related to periods of juvenile production since estuaries are used by juveniles as nursery areas (BECK et al., 2001; KRAUS; SECOR, 2005). Seasonal patterns in the abundance of fish species using the estuary during a particular period of their life history are caused by sequential, enforced migrations that occur independently of estuarine environmental conditions (POTTER et al., 1997). The variations in the fish assemblage abundance of the Pando estuary could be related to life cycle events (e.g. recruitment, juvenile migrations) but presumably they could also occur as a consequence of limitation by, e.g., extreme salinity conditions.

This paper seeks to determine the composition, structure and specific abundance of the fish assemblage in the Pando estuary, by season, and to analyze its temporal patterns in terms of ecological categories and the impact of abiotic factors. Given the bioecological importance and current ecological fragility of the estuaries on the Uruguayan coast (DEFEO et al., 2009), this study should contribute to an interpretation of the use of the Pando estuary by its various fish populations and to present knowledge of the level and characteristics of this estuary as a nursery area.

\section{Material and Methods}

\section{Study Site}

The Río de la Plata is a micro tidal coastal plain temperate estuary draining the second largest basin of South America. The main tributaries are the Paraná and Uruguay rivers which together provide 97\% of the water discharge (NAGY et al., 1996; GUERRERO et al., 1997). Several streams distributed along the northern coast of the Rio de la Plata estuary discharge their waters into it (Fig. 1). One of those streams, the Pando stream, drains a basin of $974 \mathrm{~km}^{2}$ and has an average flow of $10.9 \mathrm{~m}^{3} \mathrm{~s}^{-1}$. At the mouth of the Pando stream there is a small, shallow, protective estuary, characterized by strong erosion that modifies the regional morphology (GUTIERREZ; PANARIO, 2006). This study focuses on the Pando estuary $\left(34^{\circ}\right.$ $47^{`} \mathrm{~S}-55^{\circ} 52^{`} \mathrm{~W}$ ) (Fig. 1). It has a maximum width of $270 \mathrm{~m}$, decreasing at the mouth, and delimiting a total area of approx $170,000 \mathrm{~m}^{2}$ with an average depth of 
$1.5 \mathrm{~m}$. During 1995 and 1996 salinity and temperature were recorded in summer $\left(\mathrm{S}=17-20 ; \mathrm{T}=21-23^{\circ} \mathrm{C}\right)$ and in autumn ( $\mathrm{S}=5-15 ; \mathrm{T}=13-14{ }^{\circ} \mathrm{C}$ ) (AMORÍN; CABAL, 1996). The marine-fluvial water of the Pando estuary may be affected by two different sources: a) local, as a consequence of variations in the freshwater flow entering the estuary from the Pando stream; b) regional, as a result of brackish water from the Río de la Plata. Winds generally blow from the E-NE during the summer and produce an outflow of water from the estuary along the Uruguayan coast (north-northeasterly drift). (GUERRERO et al., 1997). There is no clearly defined annual rainfall cycle on the Uruguayan coast. Minimum rainfall in winter and in summer is mainly recorded. In the last two decades there has been an increase in precipitation in the intermediate seasons, with an especially large increase in spring (BIDEGAIN et al., 2005).

\section{Sampling design}

Fish samples were taken monthly between May 2002 and June 2003. A survey was undertaken to assess the adequacy of the sampling equipment with regard to the physical characteristics of the sampling sites and the efficiency of the nets (ROZAS; MINELLO, 1997; GUEST et al., 2003). Two sets of gear were used: a guild net $(50 \mathrm{~m}$ in length with a 40 $\mathrm{mm}$ mesh) and a beach seine (12 $\mathrm{m}$ long with a central bag: mesh size $12 \mathrm{~mm}$; cod-end, $6.70 \mathrm{~m}$ long, $2 \mathrm{~m}$ high with two lateral wings each $5 \mathrm{~m}$ in length). The capture of the latter gear was characterized by: a large number of species, juveniles of target species being significantly represented, and adult individuals also being collected. Sampling efficiency inevitably varies by species and size-class (ROZAS; MINELLO, 1997), but reasonable consistency between samples was assumed (ELLIOTT; HEMINGWAY, 2002). A beach seine was used, as suggested, for shallow water and soft bottom estuary characteristics (e.g., Patos Lagoon: Garcia et al., 2001; shallow water-Singapore: Hajisamaea et al., 2003; Ria Aveiro: Pombo et al., 2005; Guadiana Estuary: Sá et al., 2006; Zrmanja Estuary: Matic-Skoko et al., 2007). The capture with the beach seine was considered for calculation in this paper. Six hauls were made, three on each margin of the Pando estuary, at $500 \mathrm{~m}$ from its mouth, at a mean depth of $1.5 \mathrm{~m}$, at sunset (Fig 1). Two $25 \mathrm{~m}$ ropes, each of which joined to one end of the beach seine, were used for the haul. One of the ropes was retained on the beach while the other end, together with the net, was deployed by a small rowing boat. The haul was made manually and perpendicularly towards the shore, using both ropes. The net was kept as close to the bottom as possible to force the catch into the center bag. The beach seine was pulled in such a way as to cover an area of ca. $300 \mathrm{~m}^{2}$.

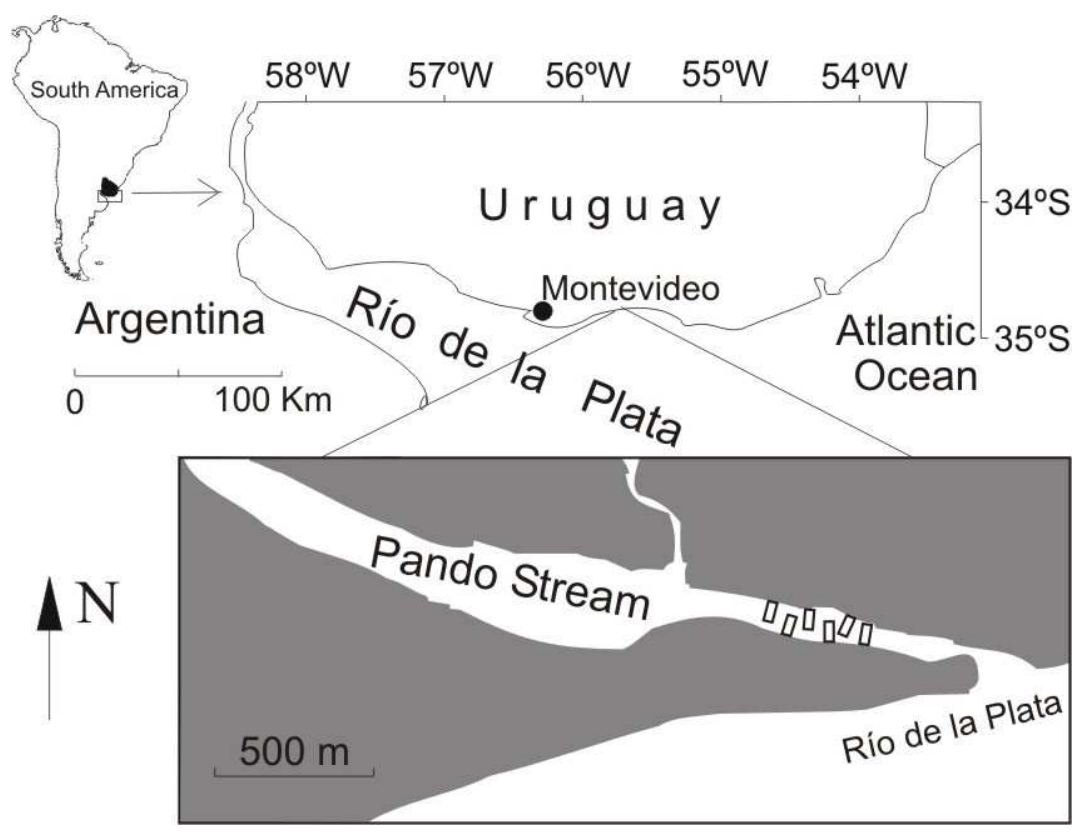

Fig. 1. Geographical location of Pando estuary showing the fishing trawl area (rectangles) on both margins of the Pando mouth. 


\section{Environmental data}

Environmental data from the Pando estuary, the Río de la Plata estuary and the Uruguay River were obtained from several sources (Table 1). The temperature and conductivity of the Pando estuary were measured at the fish sampling sites (Fig. 1) using a WTW conductimeter; the salinity was calculated from the values obtained for conductivity and temperature. Daily and monthly average temperatures and the salinity of the Río de la Plata (RP) were provided by the Servicio de Oceanografia, Hidrografía y Meteorología de la Armada (SOHMA), from the Punta Carretas station ( $28 \mathrm{~km}$ to the west of the study area). The Uruguay River runoff was also provided by SOHMA. Rainfall and wind speed records were provided by the Dirección Nacional de Meteorología, Uruguay from the weather station at Carrasco $(21 \mathrm{~km}$ to the northwest of the study area). Rainfall data were used for: (1) the cumulative rainfall of the 10 days before each sampling date, and (2) the daily rainfall of the day before each sampling date. Wind data were used to provide: (1) the maximum and (2) the average wind speed during the six hours before the sampling started.

\section{Fish data analyses}

All individuals were counted and identified by taxonomic keys (FIGUEIREDO; MENEZES, 1978, 1980, 2000; MENEZES et al., 1980, 1985; MENNI et al., 1984). Fish total length and body weight were measured to the nearest $1 \mathrm{~mm}$ and $0.01 \mathrm{~g}$, respectively. Size classes (juveniles, adults) of Micropogonias furnieri, Mugil platanus, Paralichthys orbignyanus and Brevoortia aurea were established in accordance with Cortina and Lasta (1986) and Lasta (1995), Esper et al., (2001), Mellito et al., (1995), and Acha and Macchi (2000), respectively. To classify the fish assemblage of the Pando estuary, the fish species were grouped in accordance with Elliott et al. (2007). The groups considered were: marine straggler; freshwater straggler; marine migrant; catadromous; anadromous; semi-catadromous; semi-anadromous; amphidromous; freshwater migrant; estuarine (resident + migrant).

\section{Statistical Analyses}

The environmental variables (Table 1) were analyzed by Principal Component Analysis (PCA) to determine the most influential variables. The data were centered and standardized before the analysis in order to adapt the variables to one common scale; the contribution of each variable to the formation of each axis being established from the coefficients of the eigenvectors (CLARKE; WARWICK, 1994). Community dynamics were evaluated using species abundance data through principal coordinate analysis (PCO) after logarithmic transformation and the BrayCurtis similarity index. The relationships between community dynamics and environmental variables were explored (1) by correlating the axes of PCO with environmental variables and (2) by means of Redundancy Analysis (RDA: LEGENDRE; LEGENDRE, 1998) and the Canonical analysis of principal coordinates (CAP: ANDERSON; WILLIS, 2003) was computed using Anderson (2003, 2004) and the latter one based on the Bray-Curtis similarity index. For RDA, the data analysis made was similar to that made for PCO (i.e. logarithmic transformation and Bray-Curtis similarity index); the environmental data were centered and standardized as in the case of PCA. For both RDA and CAP multicollinearity among environmental variables was tested using the variance inflation factor (VIF: ZUUR et al., 2007). Multicollinearity among explanatory variables leads to an inflation of " $p$ " values. We found multicollinearity in our data set (VIF $>5$ equivalent to multiple $\mathrm{R}^{2}>0.8$ ) so we dropped three variables: (1) monthly average temperature of the Río de la Plata and (2) daily temperature of the Río de la Plata. These variables were correlated with the temperature of the Pando estuary (both $\mathrm{R}^{2} 178>0.90, \boldsymbol{p}<0.001$ ). The third variable was maximum wind speed, correlated with the average wind speed $\left(R^{2}=0.84, p<0.001\right)$.

Table 1. Environmental variables for the Pando estuary (PE), Río de la Plata (RP) and Uruguay River (UR), the units and abbreviations are shown. The variables considered for Redundancy analysis (RDA) and Canonical Analysis of Principal Coordinates (CAP): are marked with an "X". All variables were considered in Principal Component analysis.

\begin{tabular}{|c|c|c|c|c|}
\hline Variables & Units & Abbreviation & RDA & CAP \\
\hline PE temperature & ${ }^{\circ} \mathrm{C}$ & TPE & $\mathrm{X}$ & $\mathrm{X}$ \\
\hline PE salinity & PSU & SPE & $\mathrm{X}$ & $\mathrm{X}$ \\
\hline RP monthly average temperature & ${ }^{\circ} \mathrm{C}$ & TMRP & & \\
\hline RP monthly average salinity & PSU & SMRP & $\mathrm{X}$ & $\mathrm{X}$ \\
\hline $\mathrm{RP}$ daily temperature & ${ }^{\circ} \mathrm{C}$ & TRP & & \\
\hline RP daily salinity & PSU & SRP & $\mathrm{X}$ & $\mathrm{X}$ \\
\hline Average wind speed (6 hours prior to sampling) & knots & AW & & \\
\hline Maximum wind speed ( 6 hours prior to sampling) & knots & MW & $\mathrm{X}$ & $\mathrm{X}$ \\
\hline UR runoff monthly average & $\mathrm{m}^{3} \mathrm{~s}^{-1}$ & URR & $\mathrm{X}$ & $\mathrm{X}$ \\
\hline Rainfall, day before sampling date & $\mathrm{mm}$ & P1 & $\mathrm{X}$ & $\mathrm{X}$ \\
\hline Cumulative rainfall over 10 days & $\mathrm{mm}$ & P10 & $\mathrm{X}$ & $\mathrm{X}$ \\
\hline
\end{tabular}




\section{RESULTS}

\section{Environmental Variables}

Temperature showed seasonal variations (Fig. 2). TPE temperatures typically fell to their minimum $\left(12.4^{\circ} \mathrm{C}\right)$ in June and rose to their maximum $\left(25.5^{\circ} \mathrm{C}\right)$ in February (Fig. 2). Similar temperature values were recorded for the Río de la Plata. However, the SPE and salinities of the Río de la Plata presented a different annual pattern. In the first case, salinity varied markedly between values near 0 in winterspring and a maximum of 14.6 at the end of summer (February) (Fig. 2).

The highest values of cumulative rainfall occurred during summer (January and February 2003), and that for highest daily rainfall in November 2002 (Fig. 2). Maximum wind speeds were observed in August 2002, October 2002, December 2002 and February 2003 (Fig. 2). Uruguay River runoff showed a marked increase in spring, reaching maximum values in October and December 2002, (Fig. 2). The first three components of the PCA explained $74.1 \%$ of total variance. The variables with the most important temporal variation (i.e. largest contribution to the formation of the components) were: for PC-I: daily and SMRP and TPE; for PC-II: URR; and for PC-III: SPE (Table 2).

\section{Species Composition and Size Structure}

A total of 2027 individuals of 21 species belonging to 12 families of fish were collected in the Pando estuary. The most abundant species were the whitemouth croaker (Micropogonias furnieri), the mullet (Mugil platanus), the flounder (Paralichthys orbignyanus), the Brazilian menhaden (Brevoortia aurea) and the catfish (Parapimelodus valenciennis). Abundance (85.4\%) and biomass (44.4\%) of $M$. furnieri reached a peak from late summer to autumn and their minimum values in spring (Table 3). All the individuals of $M$. furnieri were juveniles belonging to the $0+(<12 \mathrm{~cm})$ and $1+(13-25 \mathrm{~cm})$ age classes. The dominant size class was the $0+$, except between October and December when the 1+ dominated (Fig. 3). M. platanus, $<40 \mathrm{~cm},(4.2 \%)$ were collected and peaked in summer and autumn (Fig. 3). In terms of biomass $P$. orbignyanus $(31.4 \%)$ was the second dominant species (Table 3). High abundance (2.8\%) occurred in winter and spring. The total length of the larger individuals was $<65 \mathrm{~cm}$; juveniles (size class $<30 \mathrm{~cm}$ ) were dominant in the samples in autumn and winter (Fig. 3). All individuals of B. aurea (2.6\%) were juveniles $(<20 \mathrm{~cm})$; individuals smaller than 10 $\mathrm{cm}$ were common and dominated the January and February samples (Fig. 3). P. valenciennis represented $1.3 \%$ of the total annual capture and the remaining species did not represent more than $1 \%$ individually (Table 3).
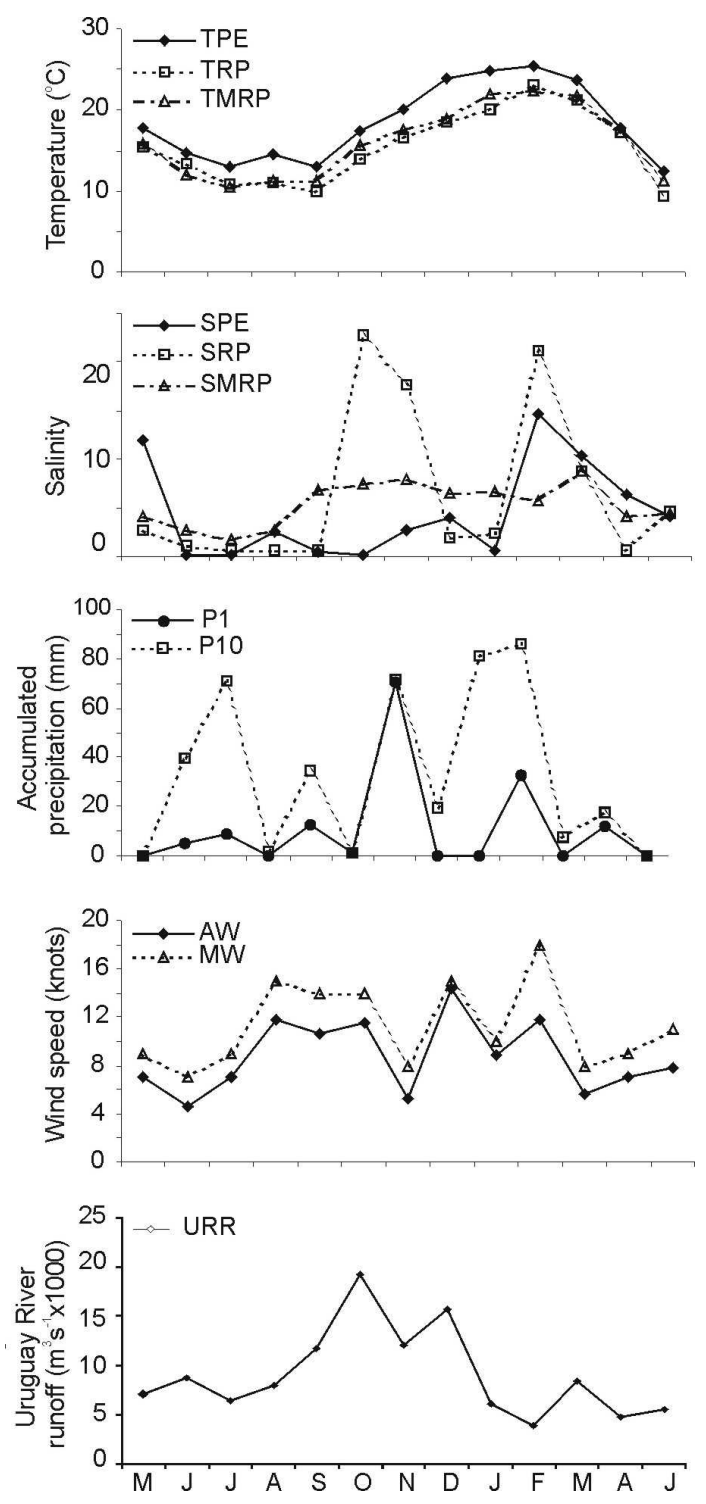

Fig. 2. Environmental variables recorded between May 2002 and June 2003. Water temperature $\left({ }^{\circ} \mathrm{C}\right)$ and salinity of the Pando estuary (PE) and adjacent waters of the Río de la Plata $(\mathrm{RP})$, rainfall $(\mathrm{mm})$, wind speed (knots) and Uruguay River runoff (URR) are shown. 
Fish Assemblage Structure and Relationships with Environmental Variables

The fish assemblage of the Pando estuary was composed of $92.9 \%$ estuarine resident and migrant species (M. furnieri, Macrodon ancylodon, Odontesthes argentinensis, Lycengraulis grossidens, Platanichthys platana, B. aurea, M. platanus and $P$. orbignyanus); of $4.7 \%$ of marine migrants (Pogonias cromis, Menticirrhus americanus and Pomatomus saltatrix) and of $1.8 \%$ of freshwater straggler species (P. valenciennis, Hoplias lacerdae, Prochilodus lineatus, Cyprinus carpio, Oligosarcus oligolepis, Pimelodus sp. and Luciopimelodus pati). Anadromous (Genidens barbus) and marine stragglers (Urophycis brasiliensis and Peprilus paru) species were classified. They were represented by values lower than $0.4 \%$. In terms of species richness, freshwater stragglers (33.3\%) and estuarine species $(33.3 \%)$ dominated the assemblage. Multiple-stepwise correlation between fish abundance by functional groups showed significant associations with SPE and TPE. The marine migrants were positively correlated to SPE (Fig. 4) and freshwater stragglers were consistently low at salinities $>8$ while they reached maximum levels at low salinity (Fig. 4). However, estuarine species correlated positively with TPE, when $M$. furnieri, the most abundant species, was not included in that group. The inclusion of M. furnieri led to a positive correlation with salinity (Fig. 4).

Table 2. Contribution of each environmental variable to the formation of the main components (PC-I, PC-II and PC-III) of the Principal Component Analysis.

\begin{tabular}{|l|c|c|c|}
\hline & PC1 & PC2 & PC3 \\
\hline TPE & $\mathbf{- 0 . 4 7 0}$ & 0.060 & -0.353 \\
\hline SPE & -0.233 & 0.282 & $\mathbf{- 0 . 6 4 0}$ \\
\hline SMRP & $\mathbf{- 0 . 4 7 5}$ & -0.258 & -0.021 \\
\hline URR & -0.159 & $\mathbf{- 0 . 6 3 4}$ & 0.276 \\
\hline AW & -0.104 & -0.434 & -0.256 \\
\hline P1 & -0.382 & 0.284 & 0.444 \\
\hline P10 & -0.262 & 0.414 & 0.344 \\
\hline SRP & $\mathbf{- 0 . 4 9 8}$ & -0.084 & 0.097 \\
\hline
\end{tabular}

Table 3. Fish assemblage composition of the Pando estuary from May 2002 to June 2003. Data presented as monthly and total abundance (N: number of individuals) and biomass (B: biomass in $\mathrm{kg} . \mathrm{km} \cdot{ }^{-2}$ ).

\begin{tabular}{|c|c|c|c|c|c|c|c|c|c|c|c|c|c|c|c|c|c|c|c|c|c|c|c|c|c|c|c|c|}
\hline \multirow{2}{*}{ SPECIES } & \multicolumn{2}{|c|}{ May. } & \multicolumn{2}{|c|}{ Jun. } & \multicolumn{2}{|c|}{ Jul. } & \multicolumn{2}{|c|}{ Aug. } & \multicolumn{2}{|c|}{ Sep. } & \multicolumn{2}{|c|}{ Oct. } & \multicolumn{2}{|c|}{ Nov. } & \multicolumn{2}{|c|}{ Dec. } & \multicolumn{2}{|c|}{ Jan. } & \multicolumn{2}{|c|}{ Feb. } & \multicolumn{2}{|c|}{ Mar. } & \multicolumn{2}{|c|}{ Apr. } & \multicolumn{2}{|c|}{ Jun. } & \multicolumn{2}{|c|}{ Total } \\
\hline & $\mathrm{N}$ & B & $\mathrm{N}$ & B & $\mathrm{N}$ & $\bar{B}$ & $\mathrm{~N}$ & B & $\mathrm{N}$ & B & $\mathrm{N}$ & B & $\mathrm{N}$ & $\bar{B}$ & $\mathrm{~N}$ & $\bar{B}$ & $\mathrm{~N}$ & $\bar{B}$ & $\mathrm{~N}$ & B & $\mathrm{N}$ & $\bar{B}$ & $\mathrm{~N}$ & B & $\mathrm{N}$ & $\bar{B}$ & $\mathrm{~N}$ & $\bar{B}$ \\
\hline Micropogogonias fumieri & 311 & 131.4 & 110 & 71.8 & 142 & 74.4 & 44 & 15.9 & 12 & 13.0 & 13 & 32.5 & 67 & 125.1 & 135 & 201.8 & 125 & $\frac{146.1}{140}$ & 182 & 183.6 & 337 & 312.2 & 115 & 125.5 & 139 & 132.9 & 1732 & 1566.4 \\
\hline Pogonias cromis & 1 & 2.24 & & & & & & & & & & & & & & & & & & & 3 & 10.1 & 1 & 4.4 & & & 5 & 16.7 \\
\hline Macrodon ancylodon & 2 & 49.3 & & & & & & & & & & & & & & & & & & & & & & & & & 2 & 49.4 \\
\hline Menticirrhus americanus & & & & & & & & & & & 1 & 1.6 & 2 & 4.2 & & & & & & & & & & & & & 3 & 5.7 \\
\hline Mugil platanus & 27 & 86.9 & 1 & 0.8 & 2 & 1.1 & & & 3 & 21.7 & 1 & 16.5 & 1 & 13.7 & & & 3 & 52.1 & 18 & 299.8 & 19 & 8.6 & 2 & 12.9 & 9 & 27.3 & 86 & 541.6 \\
\hline Pomatomus saltatrix & & & & & & & & & & & & & & & & & 2 & 11.6 & & & & & & & & & 2 & 11.6 \\
\hline Odontesthes argentineensis & 1 & 8.5 & & & & & & & & & 1 & 0.9 & & & & & 6 & 23.5 & 4 & 36.5 & 3 & 3.2 & 3 & 16.3 & & & 18 & 88.9 \\
\hline Lycengraulis grossidens & 1 & 0.9 & & & & & 4 & 1.8 & & & & & 1 & 0.4 & 3 & 3.7 & & & 3 & 7.0 & 5 & 5.5 & & & & & 17 & 19.4 \\
\hline Platanichthys platana & 3 & 1.3 & & & & & & & & & & & 3 & 1.1 & & & & & & & & & & & & & 6 & 2.4 \\
\hline Parapimelodus valenciennis & & & 5 & 4.4 & & & & & & & & & & & 9 & 10.0 & 13 & 16.6 & & & & & & & & & 27 & 31.1 \\
\hline Hoplias lacerdae & & & & & & & 1 & 0.7 & & & & & & & & & & & & & & & & & & & 1 & 0.7 \\
\hline Prochilodus inoctus & & & & & & & & & 1 & 1.3 & & & & & & & & & & & 2 & 3.4 & & & & & 3 & 4.7 \\
\hline Brevoortia aurea & & & & & & & & & & & 1 & 0.6 & 6 & 7.0 & 1 & 0.1 & 14 & 2.3 & 10 & 4.0 & 22 & 36.1 & & & & & 53 & 50.2 \\
\hline Paralichthys orbigwanus & 2 & 4.8 & 5 & 42.7 & 10 & 127.8 & 6 & 56.0 & 7 & 353.7 & 12 & 243.3 & 2 & 43.9 & 4 & 117.8 & 1 & 17.1 & & & 2 & 85.1 & 2 & 13.9 & 3 & 1.9 & 56 & 1108.1 \\
\hline Urophycis brassiliensis & & & & & & & & & & & 1 & 1.7 & & & & & & & & & & & & & & & 1 & 1.7 \\
\hline Cyprinus cappio & & & & & & & & & & & & & 1 & 2.6 & & & & & & & & & & & & & 1 & 2.6 \\
\hline 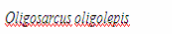 & & & & & & & & & & & & & & & 1 & 2.1 & & & & & & & & & & & 1 & 2.1 \\
\hline 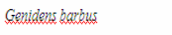 & & & & & & & & & & & & & & & & & 3 & 10.1 & 3 & 7.1 & 2 & 0.6 & & & & & 8 & 17.9 \\
\hline Pimelodidae sp. & & & & & & & & & & & & & & & & & 3 & 1.9 & & & & & & & & & 3 & 1.9 \\
\hline Peprilus paru & & & & & & & & & & & & & & & & & & & & & 1 & 0.6 & & & & & 1 & 0.6 \\
\hline Luciogimenelodus. pasti. & & & & & & & & & & & & & & & & & & & & & & & & & 1 & 1.3 & 1 & 1.3 \\
\hline
\end{tabular}



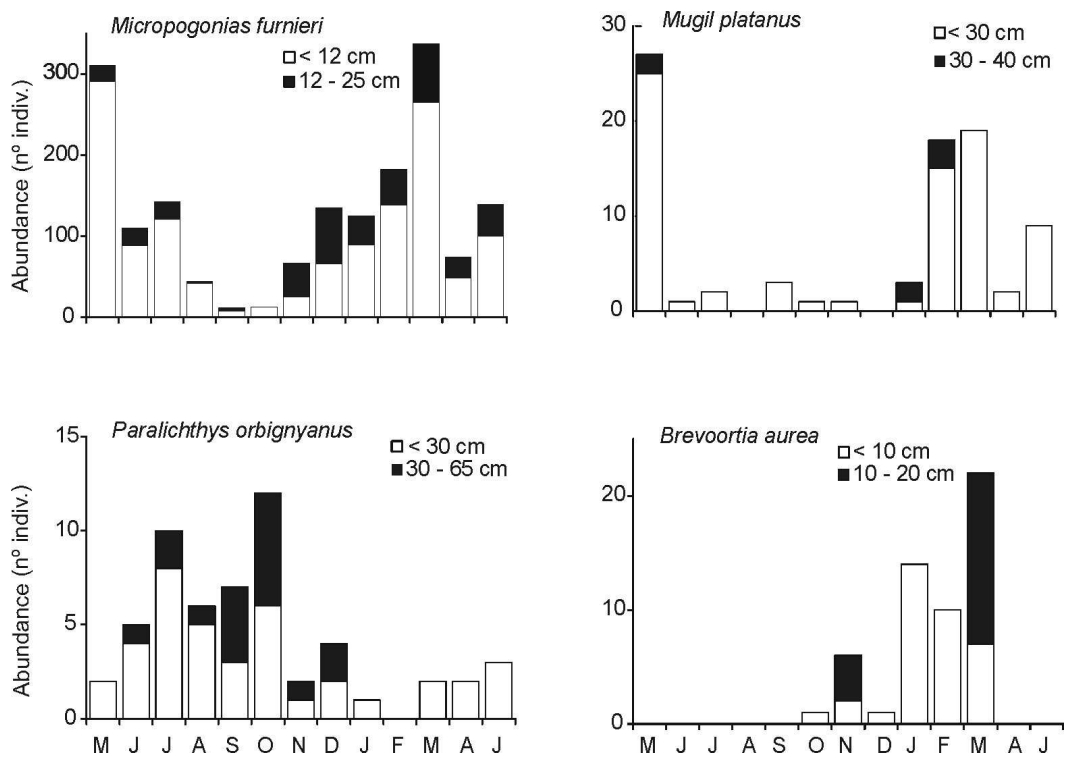

Fig. 3. Total monthly abundance and size structure of main fish species: Micropogonias furnieri, Brevoortia aurea, Paralichthys orbignyanus and Mugil platanus.
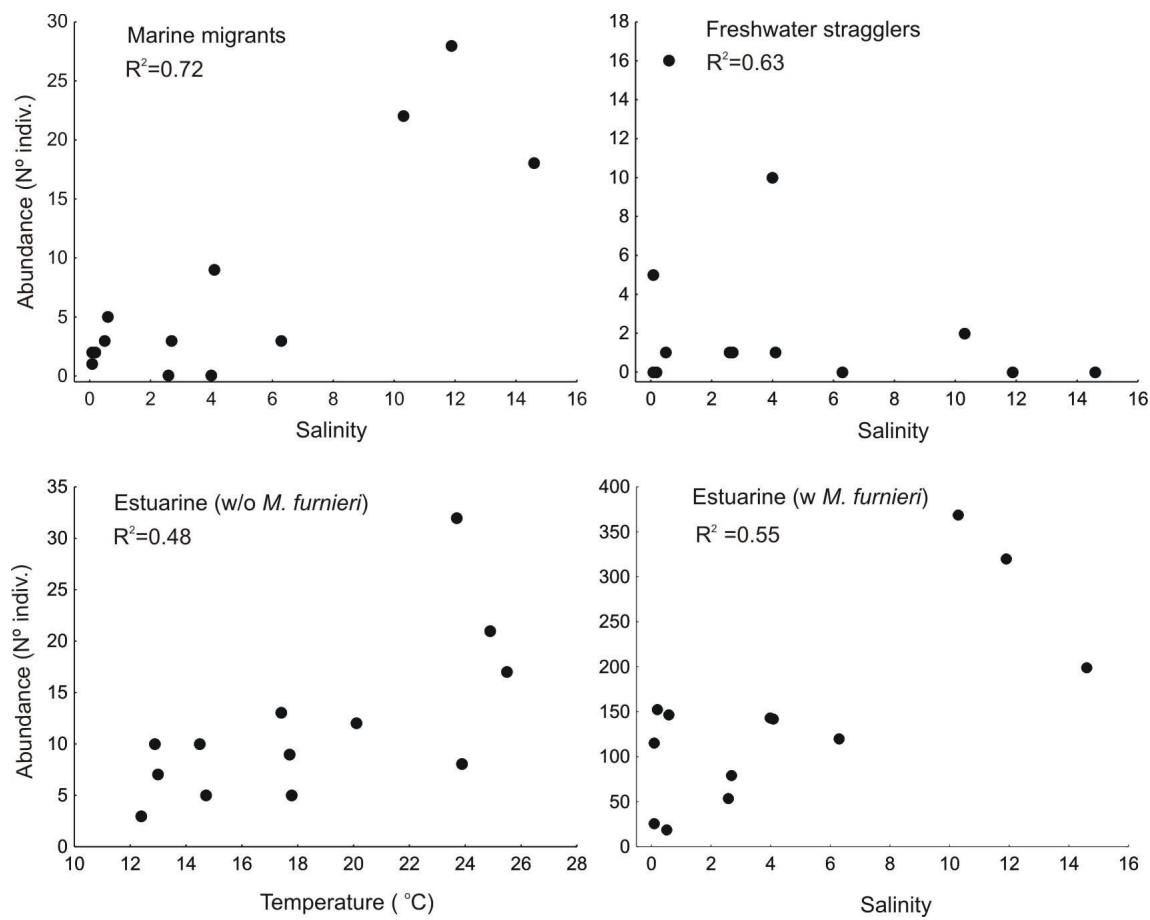

Fig. 4. Correlations between fish functional groups and TPE and SPE. For the estuarine group, correlations were made both including (w) and excluding (w/o) Micropogonias furnieri as its abundance (individuals total number) is an order of magnitude higher than that of other species. All determination coefficients are significant $(\mathrm{p}<0.05)$. 
The first two axes of the PCO explained about $70 \%$ of the temporal variability in the assemblage (Fig. 5a). There was a clear seasonal pattern with community shifts from winter-spring sampling occasions (July - October) to late springearly summer (December - January) and then shifting to late summer-autumn (February - May). During winter-spring the community was dominated by individuals of estuarine species $(60-90 \%$ of total abundance). However, in this analysis M. furnieri was not considered while in other periods dominance was below $60 \%$ of the total abundance; freshwater stragglers were more abundant in early spring-early summer $(40-50 \%)$ while marine migrants were abundant during late summer-autumn (35-70\%). A plot of the temporal changes on the first axis of the PCO shows a strong seasonality with rapid shifts on the first axis during spring and autumn (Fig. 5b). The first axis of PCO was positively correlated with the temperature $(\mathrm{r}=0.81, \mathrm{p}<0.01)$ and salinity $(\mathrm{r}=0.71, \mathrm{p}$ $<0.01)$ of the Pando estuary. Correlations with the second axis were not significant ( $p>0.05$ ).

Both RDA and CAP gave similar results (Fig. 6). The most important environmental variables were the TPE - SPE and URR. In RDA, variations in abundance of $M$. furnieri and $M$. platanus were associated with SPE; while $B$. aurea, $O$. argentinensis and $G$. barbus were associated with TPE. In CAP there were the same trends but $M$. furnieri was also linked with TPE. In addition, variations in abundance of $P$. orbignyanus were associated with low TPE and high URR runoff. Multiple-forward stepwise regressions confirmed these findings (Table 4): both M. furnieri and M. platanus were positively correlated with SPE; the other species were related to the TPE, either positively (B. aurea) or negatively $(P$. orbignyanus). Correlation with URR was significant for P. orbignyanus.
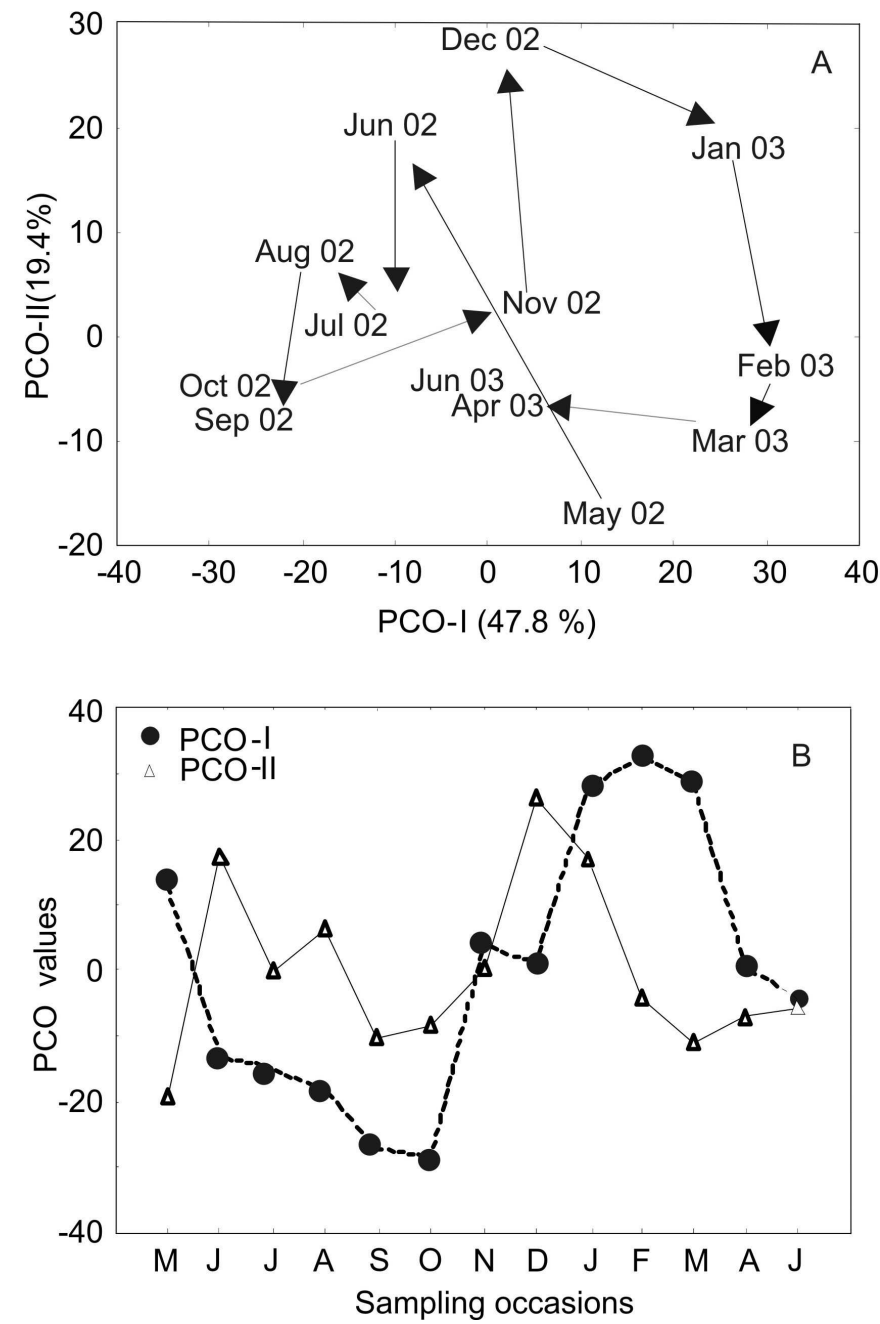

Fig. 5. Ordination based on Principal Component Analysis (PCO) applied to logarithmically transformed data of fish: (a) the first two principal coordinates for all sampling occasions; (b) temporal changes in the first two principal coordinates showing seasonality on the axis I. 

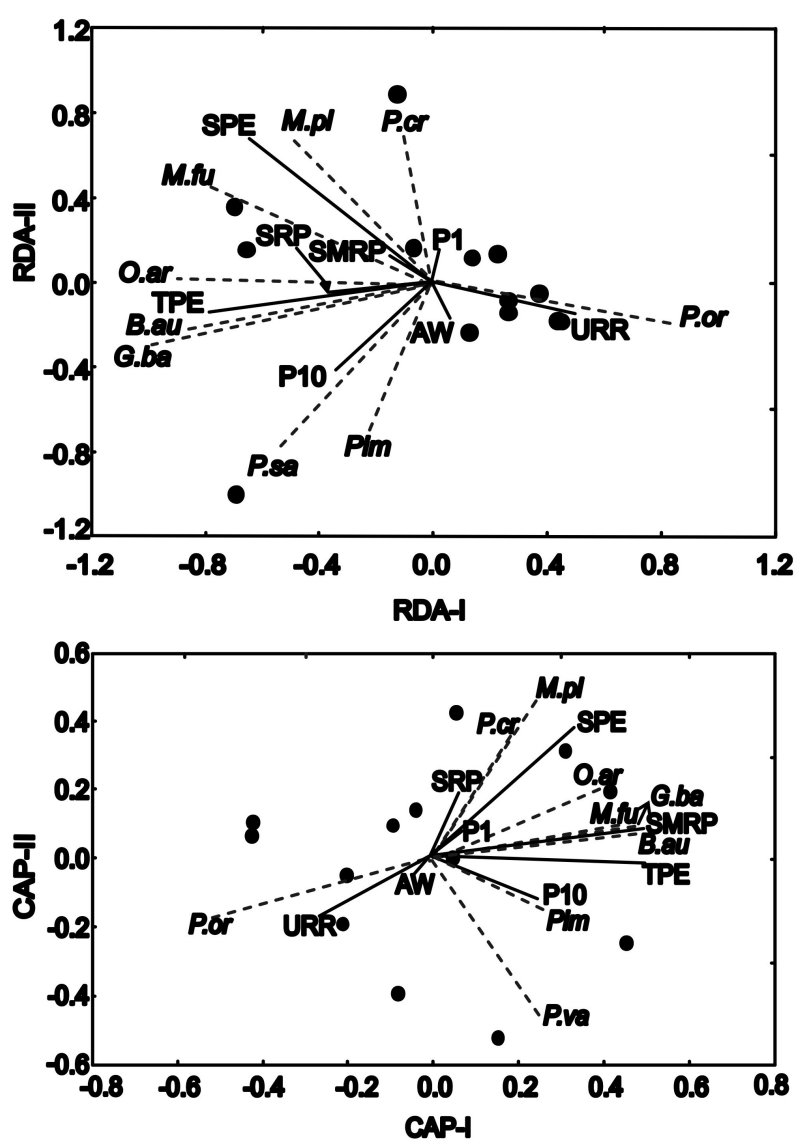

Fig. 6. Triplots of Redundancy analysis (RDA) and Canonical analysis of principal coordinates (CAP) based on fish abundance, logarithmically transformed data and environmental variables. Species and variables refer to the upper and right axes while sampling occasions refer to the lower and left axes. The sampling occasions are represented by black circles, species by dotted lines and environmental variables by lines. Species abbreviations are: B.au: Brevoortia aurea; G.ba: Genidens barbus; M.fu: Micropognias furnieri; M.pl: Mugil platanus; P.or: Paralichthys orbignyanus; P.va: Parapimelodus valenciennis; Pim: Pimelodus sp.; P.cr: Pogonias cromis; O.ar: Odonthestes argentinensis and P.sa: Pomatomus saltatrix. Environmental variables are: URR: Uruguay River runoff; AW: average wind speed; P1: rainfall of the previous day; P10: cumulative rainfall over the previous 10 days; SPE: salinity of the Pando estuary; SMRP: salinity of Río de la Plata-mean monthly values; SRP: daily salinity of Río de la Plata; TPE: temperature of the Pando estuary. Canonical eigenvalues for first and second axes were as follows: RDA $0.29,0.21$; CAP 0.98 , 0.94
Table 4. Multiple-forward regression analysis by species with salinity (SPE) and temperature (TPE) of Pando estuary and Uruguay River runoff (URR). Only significant values are shown.

\begin{tabular}{lcccc}
\hline \hline Species & SPE & TPE & URR & $\begin{array}{c}\text { Multiple } \\
\mathrm{R}^{2}\end{array}$ \\
\hline M. furnieri & 0.78 & & & 0.55 \\
M. platanus & 0.88 & & & 0.74 \\
B. aurea & & 0.74 & & 0.52 \\
P. orbignyanus & & -0.61 & 0.62 & 0.68 \\
\hline
\end{tabular}

\section{Discussion}

Fish Assemblage Composition

The number of species in the Pando estuary was consistent with what has been found in the southwest Atlantic Ocean region (Río de la Plata: Abella et al., 1979; Nión, 1996; Jaureguizar et al., 2003, 2004, 2006; Chuy Stream: Pereira et al., 1998; several estuaries of the Uruguayan coast: Giménez et al.,
2003; Retta et al., 2006; Patos Lagoon: Chao et al., 1985; Vieira; Musick, 1994; Mar Chiquita: González Castro et al., 2009a). The Pando estuary may, further, be considered to represent temperate region systems with 20 to 50 species in contrast to estuaries of tropical and subtropical regions where up to 200 species have been recorded (BLABER, 2002; ELLIOTT; HEMINGWAY, 2002; BARLETTA et al., 2003). Estuarine characteristics are low diversity but with high abundance of a few dominant species (VEIGA et al., 2006). The reduce number of some species and the abundance of a few species are a consequence of the dynamics of stressed systems, to which species adapt (ARAÚJO; COSTA DE AZEVEDO, 2001). Hence, the Pando estuary also shows the characteristics of an estuary with a low number of species and in addition, is the habitat of $M$. furnieri, the only species that reaches maximum abundance annually. Similarly, the majority of individual species were only represented by juveniles, which brings out the role of the Pando estuary as a nursery site. In fact, many authors (e.g., POTTER et al., 1990; ROUNTREE; ABLE, 1992; LAZZARI et al., 2003; VEIGA et al., 2006; MARTINHO et al., 
2007) have previously reported that estuaries and salt marshes are important for many fish species by providing food and nursery areas, shelter and protection from large piscivorous fishes (PATERSON; WHITFIELD, 2000; ELLIOTT et al., 2002). This is consistent with studies of estuarine fish worldwide, as most estuarine fish communities are dominated by juvenile stages (BLABER; BLABER, 1980; POTTER et al., 1990; VALESINI et al., 1997; PATERSON; WHITFIELD, 2000).

Life Cycle, Seasonal Variation and Environmental Influence

The Río de la Plata fish assemblage is also dominated by $M$. furnieri, which begins its life cycle when spawning in theturbidity front between November and February (ACUÑA et al., 1996; ACHA et al., 1999; BRAVERMAN et al., 2009). The age groups of $M$. furnieri occupy different habitats in the Río de la Plata estuary during the year, as determined by environmental factors (JAUREGUIZAR et al., 2003). After the spawning, the 0+ class prefer shallow and low salinity waters (CASTELLO, 1986; JAUREGUIZAR et al., 2003). Therefore, the great abundance of juveniles $<12 \mathrm{~cm}$ in the Pando estuary demonstrates that this estuary is an important refuge and feeding ground for juveniles of the species. During the spring, in the Río de la Plata, along the Uruguayan coast, bigger whitemouth croakers are predominant, and these are observed in the Pando estuary due to the presence of some individuals approximating to that size (JAUREGUIZAR et al., 2003). In late spring resumes the replacement of $0+$ juveniles coming from the Río de la Plata into the Pando estuary. Moreover, although juveniles of $M$. furnieri remain in the inner estuary, where salinity conditions may be low (see also COSTA; ARAÚJO, 2003), they do not invade freshwater habitats. Extremely low salinities in the Pando estuary may also lead to osmotic stress, thereby reducing the intrusion of individuals. Mugil platanus was the next species found in order of abundance and number and all the mullet in the Pando estuary were juveniles. This species reproduces in the open ocean and its juveniles grow within the estuaries (GARCÍA et al., 2001; GONZALEZ CASTRO et al., 2009b). This estuarine migrant is not found in the inner Río de la Plata estuary as frequently as M. furnieri (JAUREGUIZAR et al., 2006). Both in the Patos Lagoon (SW Brazil) and Mar Chiquita (NW Argentine) estuaries juvenile mullet are at maximum abundance when salinities are low (VIEIRA, 1991; GONZALEZ CASTRO et al., 2009a). In their turn, in the Pando estuary, the peaks of abundance of Paralichthys orbignyanus and Brevoortia aurea juveniles should be timed with respect to other events in the life cycle (e.g. period of larval development, maturation). The wide latitudinal distribution of $P$. orbignyanus (from Río de Janeiro, Brazil to the Argentinian coast at $40^{\circ} 50^{\prime} \mathrm{S}$ ) and $B$. aurea (Bahía, Brazil to the Argentinian coast at $41^{\circ} 30^{\prime} \mathrm{S}$ ) suggests that temperature is not be a limiting factor in our study area (COUSSEAU; PERROTA, 2000, p. 145 and 59, respectively). Most of the $P$. orbignyanus were captured in winter; in accordance with the analysis of López Cazorla (2005) for the Bahia Blanca estuary, they were mostly juveniles of the 0+ group. In Bahía Blanca, spawning occurs in summer and larvae are also found near the estuary mouth in summer (January - February). If in the Río de la Plata spawning also occurs in summer, juveniles would be expected to appear in autumn, which coincides with the increase in the abundance of the smaller individuals in the Pando estuary from late autumn to winter. Furthermore, B. aurea spawns between September and January off the Río de la Plata (ACHA; MACCHI, 2000) and on the Brazilian coast (COUSSEAU; DÍAZ DE ASTARLOA, 1993), so we would expect juveniles during the summer-autumn period. This is consistent with our findings: the smallest juveniles $(<10 \mathrm{~cm})$ were very common in summer-autumn (January - March).

There have been many interpretations offered as to what regulates fish lifespan cycles and how they are regulated Some researchers have even rejected the hypothesis that seasonal changes in estuarine fish assemblages are directly driven by variations in abiotic conditions (POTTER et al., 1986), or at least recommend that such correlations should be interpreted with great care (POTTER et al., 2001). They attribute seasonality in estuarine fish assemblages to the phasing of events that regulate spawning times and larval dispersal. In temperate estuaries, seasonal variations in abundance may be related to the timing of life cycle events (e.g. recruitment, migration: DAY et al., 1989; LEVINTON, 1995; THIEL; POTTER, 2001; VEIGA et al., 2006). The observed correlations between fish abundance and temperature should be related to life cycle variations rather than to direct responses to temperature; otherwise, correlations would reflect true cause-effect relationships. For instance, it was found in $M$. platanus that reproductive migration is also triggered by the sudden decrease of temperature (GONZALEZ CASTRO et al., 2009b).

\section{Functional Groups}

The basic ichthyofaunal structure appears to have an underlying stability and to be predictable in terms of the response of individual species to specific conditions (WITHFIELD, 1999). Hence, different taxonomic groups using the estuaries, whether on a regular or permanent basis, take advantage of the 
robust nature of the food webs within these systems. In terms of habitat use, the European estuarine fish assemblages are significantly dominated by marine species, both migrants and stragglers, followed by estuarine, freshwater, anadromous and catadromous species (FRANCO et al., 2008b). The functional group of the Pando estuary was mainly composed of estuarine and freshwater straggler species while in terms of number of individuals the majority were classified as estuarine species (ca. 93\%). Although in some cases estuarine species make an important contribution to the total abundance of the fish community (e.g. Western Australia: POTTER; HYNDES, 1999), in most estuaries, the marine migrants dominate when species biomass and number are considered (see ELLIOT et al., 2007). The reason for the dominance of freshwater stragglers and estuarine species may lie in the particular hydrological conditions of the Pando estuary. Apart from the rainfall impact on the basin and freshwater flow, salinity fluctuations must occur as the consequence of the interplay of freshwater from the rivers, entering through the head of the estuary, and seawater entering through the mouth. However, the Pando estuary has the Río de la Plata estuary as a second source of irregular salinity water whose entrance depends on the wind-driven currents (GUERRERO et al., 1997; GÓMEZ-ERACHE et al., 2000; CALLIARI et al., 2001). The influence of surrounding habitat conditions (marine and freshwater) has also been mentioned with regard to tropical estuaries (LONERAGAN et al., 1989; POTTER; HYNDES, 1999; THIEL; POTTER, 2001). In our study, this high species diversity in these groups will also be the consequence of a diverse pool of freshwater and estuarine species present in the region. South American streams and rivers present a high diversity of freshwater fish (MATTHEWS, 1998).

\section{Salinity as a Limiting Factor}

The effects of salinity in the community dynamics of the Pando estuary were detected through correlations with functional groups (marine migrants, freshwater stragglers). This reflects the fact that most of the species of fish collected in the Pando estuary occurred occasionally or seasonally (e.g. Macrodon ancylodon, Odontesthes argentinensis, Pogonias cromis). Moreover, the dominance of freshwater stragglers and estuarine species together with the correlations between abundance of the most important species suggest a key role when the community structure and dynamics in this system are to be explained. Previous studies of the estuaries on the Uruguayan coast found no clear relationship between the fish density and salinity and temperature values (RETTA et al., 2006). In the present study, for the fish assemblage of the Pando estuary, salinity can play a marked structuring role in the community. This suggests that in the Pando estuary a process of recruitment disrupted by low salinity is observed. This is, therefore, consistent with previous reports showing that variability in fish abundance can also reflect varying salinity and freshwater flow (BLABER; BLABER, 1980; FORBES; CYRUS, 1993; MARSHALL; ELLIOTT, 1998; VORWERK et al., 2003; WHITFIELD; HARRISON, 2003; JAUREGUIZAR et al., 2004). The salinity conditions in the Pando estuary during the present study were indeed extremely low (Fig. 2) as compared with those of previous studies (5-15 in autumn and 17-20 in summer ( AMORÍN; CABAL, 2006 unpublished data). The sampling period included an El Niño Southern Oscillation (ENSO) event from October 2002 to March 2003 (BIDEGAIN et al., 2005), while the study of Amorín and Cabal was carried out during La Niña of 1995-1996. The ENSO of 2002-2003 caused a great increase in river discharge on the South Atlantic coast of South America (BIDEGAIN et al., 2005), including the Pando estuary. It is, therefore, possible that the ENSO has an indirect effect on the use of the Pando estuary by juvenile fish. The ENSO has profound effects on the biota of the Pacific coast of the Americas (THATJE, 2008) and affects the recruitment and migration dynamics of fish species of the Atlantic coast through changes in freshwater flow (GARCÍA et al., 2001; GARCIA; VIEIRA, 2002). Large-scale, long-term processes can thus affect the use of the estuary by juveniles and the definition of particular habitats as nurseries.

Summarizing, this is first time that the annual variation of the composition and ichthyofauna structure has been studied in Uruguayan estuaries. Both seasonality and variations in salinity play an important role in the use of the estuary by 17 species of juvenile fish. If salinity affects the abundance of juvenile fish, any temporal fluctuation will be relevant for the definition of estuaries as nursery areas. The results presented are in agreement with Whitfield and Harrison's (2003): the value of any estuarine habitat as a nursery for fish or other species may fluctuate according to the salinity and freshwater flow conditions. This fluctuation may occur at seasonal but also on longer time scales. To put things in perspective, we need to evaluate the role of other estuaries ine South America, including those of the Uruguayan coast in order to understand the importance of environmental variability for community structure by juveniles.

\section{Conclusions}

In brief, the results show that low salinity affects the abundance of the most important species 
and most diverse functional groups. The dynamic nature of fish communities suggests that the definition of nursery areas in many estuaries may be context (= salinity) -dependent. These results also support the conclusion that both seasonality and extreme salinity conditions affect the fish community of the Pando stream. Seasonality is related to the periods of juvenile production since most of the individuals captured were juveniles.

\section{ACKNOWLEDGEMENTS}

We would like to thank the fishermen of Neptunia: Eduardo and Laura for their support with the fishing net, light, fishing vessel and their participation in the fishing activities; Carlos, who made his bus available (for our use as a laboratory); Tito Olivera and Carlos who gave us their support during the sampling excursions; Professor Daniel Panario who lent us his rowing boat; J. Rapetti, J. Frances, C. Ferrari, M. Trimble and Ph. Miller who helped us with field and laboratory activities, and especially all the working team of the IctioPando Project for helping us with sampling, field and laboratory work: F. Viana, A. Carnikian, B. Musso, R. Canavese, J. Richly, M. Zarucki, F. Vásquez, N. Borba and H. Ferrando. The Prefectura Naval of La Floresta and Solymar supported us with the inflatable boat and rescue personnel. Environmental data were provided by Servicio de Oceanografía y Meteorología de la Armada and Dirección Nacional de Meteorología of Uruguay.

\section{REFERENCES}

ABELlA, A.; ARENA, G.; NIÓN, H.; RÍOS, C. Peces bentónicos del Río de la Plata y de la zona común de pesca Argentino-Uruguaya. In: UNESCO (Ed.). Memorias del seminario sobre ecología bentónica y sedimentación de la plataforma continental del Atlántico Sur. Montevideo, 1979. p. 291-323.

ABLE, K.W. A re-examination of fish estuarine dependence: evidence for connectivity between estuarine and ocean habitats. Est.uar. coast. Shelf Sci. v. 64, p. 5-17, 2005.

ACUÑA, A.; ARENA, G.; BEROIS, N.; MANTERO, G.; MASELLO, A., NIÓN, H.; RETTA, S.; RODRÍGUEZ $\mathrm{M}$. The whitemouth croaker (Micropogonias furnieri): biological cycle and fisheries in the Río de la Plata and its oceanic front. In: WELLS, P. G.; DABORN, G. R. (Ed.). The Río de la Plata. An environmental overview. An Ecoplata Project Background Report. Dalhousie University, Halifax, Nova Scotia, Canada. 1996, p. 185-222.

ACUÑA, A.; VIANA, F.; VIZZIANO, D.; DANULAT, E. Reproductive cycle of female Brazilian codling, Urophycis brasiliensis (Kaup 1858), caught off the
Uruguayan coast. J. appl. Ichthyol., v. 16, p. 48-55, 2000.

ACHA, E. M.; MACCHI, G. J. Spawning of Brazilian menhaden, Brevoortia aurea, in the Río de la Plata estuary off Argentina and Uruguay. Fish. Bull., v. 98, p. 227-235, 2000

ACHA, E. M.; MIANZAN, H.; LASTA, C. A.; GUERRERO, R.A. Estuarine spawning of the whitemouth croaker Micropogonias furnieri (Pisces: Sciaenidae), in the Río de la Plata, Argentina. Mar. Freshw. Res., v. 50, p. 57-65, 1999.

AKIN, S.; BUHAN, E.; WINEMILLER, K. O.; YILMAZ, H. Fish assemblage structure of Koycegiz lagoon-estuary, Turkey: spatial and temporal distribution patterns in relation to environmental variation. Estuar. coast. Shelf Sci., v. 64, p. 671-684, 2005.

AMORÍN, C.; CABAL, C. Informe de calidad del agua del Arroyo Pando. APRAPANDO. Montevideo: Universidad de la República, Facultad de Ingeniería, 1996.

ANDERSON, M. J. PCO: a FORTRAN computer program for principal coordinate analysis. Department of Statistics, University of Auckland, New Zealand. 2003.

ANDERSON, M. J. CAP: a FORTRAN computer program for canonical analysis of principal coordinates. Department of Statistics, University of Auckland, New Zealand. 2004.

ANDERSON, M. J.; WILLIS, T. J. Canonical analysis of principal coordinates: an ecologically meaningful approach for constrained ordination. Ecology, v. 84, p. 511-525, 2003.

ARAÚJO, F. G.; COSTA DE AZEVEDO, M. C. Assemblages of Southeast-South Brazilian Coastal Systems Based on the Distribution of Fishes Estuar. coast. Shelf Sci., v. 52, p. 729-738, 2001.

BARLETTA, M.; BARLETTA-BERGAN, A.; SAINTPAUL, U.; HUBOLD, G. Seasonal densities, biomass and diversity of estuary fishes in tidal mangrove creeks of the lower Caeté Estuary (North Brazilian Coast, east Amazon). Mar. Ecol. Progr. Ser., v. 256, p. 217-228, 2003.

BECK, M.W., HECK, K. L. JR.; ABLE, K. W.; CHILDERS, D. L.; EGGLESTON, D. B.; GILLANDERS, B.M.; HALPERN, B.; HAYS, C. G.; HOSHINO, K.; MINELLO, T.J.; ORTH, R. J.; SHERIDAN, P. F.; WEINSTEIN, M. P. The identification, conservation, and management of estuarine and marine nurseries for fish and invertebrates. BioScience, v. 51, n. 8, 633-641, 2001

BIDEGAIN, M.; CAFFERA, F. R. M.; BLIXEN, F.; PSHENNIKOV, V.; LAGOMARSINO, J. J.; FORBES, E. A.; NAGY, G. J. Tendencias climáticas, hidrológicas y oceanográficas en el Río de la Plata y costa uruguaya. In: BARROS, V.; MENÉNDEZ, A.; NAGY, G., (Eds.). El cambio climático en el Río de la Plata. Buenos Aires: CIM, CONICET, 2005. p. 137-143.

BLABER, S. J. M. 'Fish in hot water': the challenges facing fish and fisheries research in tropical estuaries. J. Fish Biol., v. 61, p. 1-20, 2002.

BLABER, S. J. M.; BLABER, T.G. Factors affecting the distribution of juvenile estuarine and inshore fish. J. Fish Biol., v. 17, p. 143-162, 1980 
BRAVERMAN, M. S.; ACHA, E. M.; GAGLIARDINI, D.; RIVAROSSA, M. Distribution of whitemouth croaker (Micropogonias furnieri, Desmarest 1823) larvae in the Río de la Plata estuarine front. Estuar. coast. Shelf Sci., v. 82, p. 557-565, 2009.

CALLIARI, D.; CERVETTO, G.; GÓMEZ, M. Short-term variability in abundance and vertical distribution of the opossum shrimp Neomysis americana in the Solís Grande River Estuary, Uruguay. Atlântica, v. 23, p. 117125, 2001.

CASTELLO, J. P. Distribución, crecimiento y maduracion sexual de la corvina juvenil (Micropogonias furnieri) en el estuario de la Lagoa dos Patos, Brasil. Phycis, v. 44, p. 21-36, 1986.

CHAO, L. N., PEREIRA, L. E.; VIEIRA, J. P. Estuarine fish community of the dos Patos Lagoon, Brasil: A baseline study. In: YÁÑEZ-ARANCIBIA, A. (Ed.). Fish community Ecology in estuaries and coastal lagoons: Towards an ecosystem integration. Press México, DR (R) UNAM, , 1985. p. 429-450.

CLARKE, K. R.; WARWICK, R. M. Change in marine communities: An approach to statistical analysis and interpretation. Plymouth Marine Laboratory, UK., 1994.

CORTINA, C. P.; LASTA, C. Estudio preliminar de la determinación de edad en la corvina (Micropogonias furnieri). Publ Com Tec Mix Frente Marit. v. 1, n. 2, 311-318, 1986.

COSTA, M. R.; ARAÚJO, F.G. Use of a tropical bay in southeastern Brazil by juvenile and subadult Micropogonias furnieri (Perciformes, Scianidae). ICES J. mar. Sci., v. 60, p. 268-277, 2003.

COSTA, M. J.; CABRAL, H. N.; DRAKE, P.; ECONOMOU, A. N.; FERNANDEZ-DELGADO, C.; GORDO, L.; MARCHAND, J.; THIEL, R. Links between fish and other trophic levels. In: ELLIOT, M.; HEMINGWAY, K. L. (Ed.). Fishes in estuaries. USA: Blackwell Science, 2002. p. 54-123.

COUSSEAU, M. B.; DÍAZ DE ASTARLOA, J. M. El género Brevoortia en la costa atlántica sudamericana. Frente Marit., v. 14, p. 49-57, 1993.

COUSSEAU, M. B.; PERROTA, R. G. Peces Marinos de Argentina: Biología, distribución y pesca. Mar del Plata: INIDEP, 2000.

DAY, J. W.; HALL, CH. A. S.; KEMP, W. M.; YÁNEZARANCIBIA, A. Estuarine Ecology. New York, NY: Wiley J and Sons, 1989.

DEFEO, O.; HORTA, S.; CARRANZA, A.; LERCARI, D.; DE ALAVA, A.; GOMEZ, J.; MARTINEZ, G.; LOZOYA, J. P.; CELENTANO, E. Hacia un manejo ecosistémico de las pesquerías. Áreas Marinas Protegidas en Uruguay. Montevideo: Facultad de Ciencias-DINARA, 2009, $122 \mathrm{p}$.

EcoPLATA. Diagnóstico ambiental y socio-demográfico de la zona costera uruguaya del Río de la Plata. Compendio de los principales resultados. LÓPEZLABORDE, J.; PERDOMO, A.; GÓMEZ-ERACHE, M. (Ed.). Montevideo,Uruguay. 2000. 180 p.

ELLIOTT, M.; HEMINGWAY, K. L. Fish in Estuaries. Oxford: Blackwell Science, 2002.636 p.

ELLIOTT, M.; WHITFIELD, A. K.; POTTER, I. C.; BLABER, S. J. M.; CYRUS, D. P.; NORDLIE, F. G.; HARRISON, T. D. The guild approach to categorizing estuarine fish assemblages: a global review. Fish Fish., v. 8 , p. 241-268, 2007.
ESPER, P. M. L.; SANTOS DE MENEZES, M.; ESPER, W. Reproductive epoch of Mugil platanus (Günther, 1880), (Pisces, Mugilidae) from the Baia de Paranaguá (Paraná, Brazil). Acta Biol. Par., Curitiba, v. 30, p. 5-17, 2001.

FIGUEIREDO, J. L.; MENEZES, N. A. Manual de peixes marinhos do sudeste do Brasil. II. Teleostei (1). São Paulo: Museu de Zoologia, Universidade de São Paulo, 1978.

FIGUEIREDO, J. L.; MENEZES, N. A. Manual de peixes marinhos do sudeste do Brasil. III. Teleostei (2). São Paulo: Museu de Zoologia, Universidade de São Paulo, 1980.

FIGUEIREDO, J. L.; MENEZES, N. A. Manual de peixes marinhos do sudeste do Brasil. VI. Teleostei (5). São Paulo: Museu de Zoologia, Universidade de São Paulo, 2000

FORBES, A. T.; CYRUS, D. P. Biological effects of salinity gradient reversals in southeast African estuarine lake. Aquat. Ecol., v. 27, p. 265-272, 1993.

FRANCO, A., ELLIOTT, M.; FRANZOI, P.; TORRICELLI1, P. Life strategies of fishes in European estuaries: the functional guild approach. Mar. Ecol Progr Ser., v. 354, p. 219-228, 2008 a.

FRANCO, A.; FRANZOI, P.; TORRICELLI, P. Structure and functioning of Mediterranean lagoon fish assemblages: A key for the identification of water body types. Estuar. coast. Shelf Sci., v. 79, p. 549-558, 2008b.

FREPLATA. Análisis diagnóstico transfronterizo del Río de la Plata y su Frente Marítimo. Documento Técnico. Proyecto: "Protección Ambiental del Río de la Plata y su Frente Marítimo: Prevención y Control de la Contaminación y Restauración de Hábitats". Proyecto Freplata - PNUD/GEF. RLA/99/G31, 2005. $311 \mathrm{p}$.

GARCIA, A. M.; VIEIRA, J. The link between El Niño, freshwater outflow and the dynamics of an estuarine fish assemblage in South Brazil. Estuar. Coast. Sci. Assoc. Bull., v. 41, p. 36-37, 2002.

GARCÍA, A. M.; VIEIRA, J. P.; WINEMILLER, K. O. Dynamics of the shallow-water fish assemblage of the Patos Lagoon estuary (Brazil) during cold and warm ENSO episodes. J. Fish Biol., v. 59, p. 1218-1238, 2001.

GIMÉNEZ, L.; VEROCAI, J.; CARRANZA, A.; BORTHAGARY, A.; RODRÍGUEZ, M.; SAONA, G. Informe final del Proyecto: "Relevamiento de la biodiversidad costera de Uruguay: Invertebrados bentónicos y peces". Proyecto de Protección Ambiental del Río de la Plata y su Frente Marítimo. Proyecto FREPLATA- PNUD/GEF. RLA/99/G31. 2003. (Available at:http://www.freplata.org/documentos/archivos/Documentos_Fr eplata/Invertebrados_y_Peces- Informe-Final.pdf)

GIMÉNEZ, L.; BORTHAGARAY, A. I.; RODRÍGUEZ, M. BRAZEIRO, A.; DIMITRIADIS, C. Scale-dependent patterns of macrofaunal distribution in soft-sediment intertidal habitats along a large-scale estuarine gradient. Helgol. Mar. Res., v. 59, p. 224-236, 2005.

GÓMEZ-ERACHE, M.; NORBIS, W.; BASTRERI, D. Wind effect as forcing factor controlling distribution and diversity of copepods in a shallow temperate estuary (Solís Grande, Uruguay). Sci. Mar., v. 64, p. 87-95, 2000. 
GONZÁLEZ CASTRO, M.; DÍAZ DE ASTARLOA, J. M.; COUSSEAU, M. B.; FIGUEROA, DE; DELPIANI. SM; BRUNO DO, GUZZONI JM, BLASINA GE. AND DELI ANTONI, M. Y. Fish composition in a SouthWestern Atlantic temperate coastal lagoon: spatialtemporal variation and relationships with environmental variables. J. mar. Biol. Assoc. UK., p. 1-12, 2009a.

GONZÁLEZ CASTRO, M.; ABACHIAN, V.; PERROTTA, R. G. Age and growth of the striped mullet, Mugil platanus (Actinopterygii, Mugilidae), in a southwestern Atlantic coastal lagoon $\left(37^{\circ} 32^{\prime} \mathrm{S}-57^{\circ} 19 \mathrm{~W}\right)$ : a proposal for a life-history model. J. Appl. Ichthyol., v. 25, p. 61$66,2009 b$.

GUERRERO, R. A.; ACHA, E. M.; FRAMIÑAN, M. B.; LASTA, C. A. Physical oceanography of the Río de la Plata estuary, Argentina. Continent. Shelf Res., v. 17, p. 727-742, 1997.

GUEST, M. A.; CONNOLLY, R. M.; LONERAGAN, N. R. Seine nets and beam trawls compared by day and night for sampling fish and crustaceans in shallow seagrass habitat Fish. Res., v. 64, p. 185-196, 2003.

GUTIÉRREZ, O.; PANARIO, D. Evolución de la desembocadura del Arroyo Pando (Canelones, Uruguay): ¿tendencias naturales o efectos antrópicos?. In: MENAFRA R., RODRÍGUEZ-GALLEGO, L., SCARABINO, F., CONDE, D. (Ed.). Bases para la conservación y el manejo de la costa uruguaya. 2006, p. 391- 400.

HAJISAMAEA, S.; CHOUA, L. M.; IBRAHIMB, S. Feeding habits and trophic organization of the fish community in shallow waters of an impacted tropical habitat Estuar.coast. Shelf Sci., v. 58, p. 89-98, 2003.

JAUREGUIZAR, A. J.; MENNI, R.; BREMEC, C. MIANZAN, H.; LASTA, C. Fish assemblage patterns in the Río de la Plata estuary. Estuar. coast. Shelf Sci., v. 56, p. 921-933, 2003.

JAUREGUIZAR, A. J.; MENNI, R.; GUERRERO, R.; LASTA, C. Environmental factors structuring fish communities of the Río de la Plata estuary. Fish. Res., v. 66, p. 195-211, 2004.

JAUREGUIZAR, A. J.; MENNI, R.; LASTA, C. GUERRERO, R. Fish assemblages of the northern Argentine coastal system: spatial patterns and their temporal variations. Fish. Oceanogr., v. 15, p. 326-344, 2006.

KJERFVE, B. Coastal Lagoons. In: KJERFVE, B., (Ed.) Coastal lagoon processes. Amsterdam: Elsevier Science Publishers, 1994. p. 1-8.

KRAUS, R. T.; SECOR, D. H. Application of the nurseryrole hypothesis to an estuarine fish. Mar. Ecol. Prog. Ser., v. 291, p. 301-305, 2005.

LASTA, C. A. La Bahía Samborombón: zona de desove y cría de peces. Ph.D. Thesis, Universidad Nacional de La Plata, Argentina. 1995.

LAZZARI, M. A.; SHERMAN, S.; KANWIT, J. K. Nursery use of shallow habitats by epibenthic fishes in Maine nearshore waters. Estuar. coast. Shelf Sci., v. 56, p. 73 84, 2003.

LEGENDRE, P.; LEGENDRE, L. Numerical Ecology. Developments in Environmental Modelling. Amsterdam: Elsevier Publishers, 1998.

LEVINTON, J. S. Marine Biology. Function, Biodiversity, Ecology. New York, NY: Oxford University Press, New York. 1995.
LONERAGAN, N. R.; POTTER, I. C.; LENANTON, R. C. J. Influence of site, season and year on contributions made by marine, estuarine, diadromous and freshwater species to the fish fauna of a temperate Australian estuary. Mar. Biol., v. 103, p. 461-479, 1989.

LÓPEZ CAZORLA, A. On the age and growth of flounder Paralichthys orbignyanus (Jenyns, 1842) in Bahía Blanca estuary, Argentina. Hydrobiologia, v. 537, p. 8187, 2005.

MACCHI, G. J.; ACHA, M. E. Spawning frequency and batch fecundity of Brazilian menhaden, Brevoortia aurea, in the Río de la Plata estuary off Argentina and Uruguay. Fish. Bull., v. 98, p. 283-289, 2000.

MACCHI, G. J.; ACHA, M. E.; LASTA, C. A. Desove y fecundidad de la corvina rubia Micropogonias furnieri (Desmarest, 1823) del estuario del Río de la Plata, Argentina. Bol. Inst. Esp. Oceanogr., v. 12, p. 99-13, 1996.

MACCHI, G. J.; ACHA, M. E.; MILITELLI, M. I. Seasonal egg production of whitemouth croaker (Micropogonias furnieri) in the Río de la Plata estuary, ArgentinaUruguay. Fish. Bull., v. 101, p. 332-342, 2003.

MAES, J.; VAN DAMME, S.; MEIRE, P.; OLLEVIER, F. Statistical modeling of seasonal and environmental influences on the population dynamics of an estuarine fish community. Mar. Biol. v. 145, p. 10331042, 2004.

MARSHALL, S.; ELLIOTT, M. Environmental influences on the fish assemblage of the Humber estuary, UK. Estuar. coast. Shelf Sci., v. 46, p. $175-184,1998$.

MARTINHO, F.; LEITÃO, R.; VIEGAS, I.; DOLBETH, M.; NETO, J. M.; CABRAL, H. N. The influence of an extreme drought event in the fish community of a southern Europe temperate estuary.. Estuar. coast. Shelf Sci., v. 75, p.537-546, 2007.

MATIĆ-SKOKO, S. S.; PEHARDA, M. PALLAORO, A. CUKROV, M.; BAŽDARIĆ, B. Infralittoral fish assemblages in the Zrmanja estuary, Adriatic. Acta Adriat., v. 48, n. 1, p. 45-55, 2007.

MATTHEWS, W. J. Patterns in freshwater fish ecology.New York, NY: Chapman and Hall; Kluwer Academic Press, 1998.

MELLITO DA SILVEIRA, M. P.; BRAHAM COUSIN, J. C.; HAIMOVICI, M. Estrutura ovárica e testicular do linguado Paralichthys orbignyanus (Valenciennes, 1839). Atlântica, v. 17, p. 135-152, 1995.

MENEZES, N. A.; FIGUEIREDO, J. L. Manual de peixes marinhos do sudeste do Brasil. IV. Teleostei (3). São Paulo: Museu de Zoologia, Universidade de Sao Paulo, 1980

MENEZES, N. A.; FIGUEIREDO, J. L. Manual de peixes marinhos do sudeste do Brasil. V. Teleostei (4). São Paulo: Museu de Zoologia, Universidade de Sao Paulo, 1985.

MENNI, R. C.; RINGUElET, R. A.; ARAMBURU, R. H. Peces marinos de la Argentina y Uruguay. Buenos Aires: Editorial Hemisferio Sur, 1984

MOYLE, P. B.; CECH, JR. J. J. Fishes. An introduction to ichthyology. 5th edition. Englewood Cliffs, NJ: PrenticeHall. 2004.

NAGY, G. J.; MARTÍNEZ, C. M.; CAFFERA, R. M.; PEDROSA, G.; FORBES, E. A.; PERDOMO, A. C.; LÓPEZ LABORDE, J. The hydrological and climatic setting of the Río de la Plata. In: WELLS, P. G.; 
DABORN, G. R. (Ed.). The Río de la Plata. An environmental overview. An EcoPlata Project Background Report. Halifax, Nova Scotia: Dalhousie University, Halifax, 1996 . p. 17-70.

NIÓN, H. Fishes of the Río de la Plata and some aspects of their ecology. In: WELLS, P.G.; DABORN, G. R. (Ed.). The Río de la Plata. An environmental overview. An Project Background Report. Halifax, Nova Scotia: Dalhousie University, 1996. p. 163-184.

NORBIS, W.; PAESCH, L.; GALLI, O. Los recursos pesqueros de la costa de Uruguay: ambiente, biología y gestión. In: MENAFRA, R.; RODRÍGUEZ-GALLEGO, L.; SCARABINO, F.; CONDE, D. (Ed. ). Bases para la conservación y el manejo de la costa uruguaya. Vida Silvestre Uruguay. Montevideo: Graphis, 2006. p. $197-$ 209.

PATERSON, A. W.; WHITFIELD, A. K. Do shallow-water habitats function as refugia(refuges ?) for juvenile fishes? Estuar. coast. Shelf Sci., v. 51, p. 359-364, 2000.

PEREIRA, L. E.; RAMOS, L. A.; PONTES, S. X. Lista comentada dos peixes e crustáceos decápodos do estuario do arroio Chuí e a região costeira adjacente, RS Atlântica, v. 20, p. 165-172, 1998.

POMBO, L.; ELLIOTT, M.; REBELO, J. E. Environmental influences on fish assemblage distribution of an estuarine coastal lagoon, Ria de Aveiro (Portugal). Scien. Mar., v. 69, p. 143-159, 2005.

POTTER, I. C.; HYNDES, G.A. Composition of the fish fauna of a permanently open estuary on the southern coast of Australia and comparisons with nearby seasonally closed estuary. Mar. Biol., v. 121, p. 199209,1994

POTTER, I. C.; HYNDES. G. A. Characteristics of the ichtyofaunas of southwestern Australian estuaries, including comparisons with holartic estuaries elsewhere in temperate Australia: A review. Aust. J. Ecol., v. 24, p. 395-421, 1999.

POTTER, I. C.; CLARIDGE, P. N.; WARWICK, R. M. Consistency of seasonal changes in an estuarine fish assemblage. Mar. Ecol. Progr Ser., v. 32, p. 217-228, 1986

POTTER, I. C.; BECKLEY, L. E.; WHITFIELD, A. K.; LENANTON, R. C. J. Comparisons between the roles played by estuaries in the life cycles of fishes in temperate Western Australia and Southern Africa. Environ. Biol. Fish., v. 28, p. 143-178, 1990.

POTTER, I. C.; CLARIDGE, P. N.; HYNDES, G. A.; CLARKE, K. R. Seasonal, annual and regional variations in ichthyofaunal composition in the inner Severn estuary and inner Bristol Channel. J. mar. Biol. Assoc. U K. v. 77, p. 507-525, 1997.

POTTER, I. C.; BIRD, D. J.; CLARIDGE, P. N.; CLARKE, K. R.; HYNDES, G. A.; NEWTON, L. C. "Fish Fauna of the Severn Estuary. Are there long-term changes in abundance and species composition and are the recruitment patterns of the main marine species correlated?’. J. expl mar. Biol. Ecol. v. 258, p. 15 - 37, 2001.

RETTA, S.; MARTINEZ, G.; ERREA, A. Áreas de cría de especies de peces en la costa uruguaya. In: MENAFRA, R.; RODRÍGUEZ-GALLEGO, L.; SCARABINO, F.; CONDE, D. (Ed.). Bases para la conservación y manejo de la costa uruguaya. Vida Silvestre Uruguay. Montevideo: Graphis, 2006. p. 211-217.

ROZAS, L. P.; MINELLO, T. J. Estimating densities of small fishes and Decapod Crustaceans in shallow estuarine habitats: A review of sampling design with focus on Gear Selection. Estuarios. v. 20, n. 1, p. 199-213, 1997.

ROUNTREE, R.A.; ABLE, K. W. Fauna of polyhaline subtidal marsh creeks in Southern New Jersey: composition, abundance and biomass. Estuaries, v. 15, p. 171-185, 1992.

SÁ R.; BEXIGA, C.; VEIGA, P.; VIEIRA, L.; ERZINI, K. Feeding ecology and trophic relationships of fish species in the lower Guadiana River Estuary and Castro Marim e Vila Real de Santo Antonio Salt Marsh, Estuar. coast. Shelf Sci. v. 70, p. 19-26, 2006.

SELLESLAGH, J.; AMARA, R. Environmental factors structuring fish composition and assemblages in a small macrotidal estuary (eastern English Channel). Est. Coast. Shelf Sci., v. 79, p. 507-517, 2008.

SELLESLAGH, J.; AMARA, R.; LAFFARGUE, P.; LESOURD, S.; LEPAGE, M.; GIRARDIN, M. Fish composition and assemblage structure in three Eastern English Channel macrotidal estuaries: A comparison with other French estuaries. Estuar. coast. Shelf Sci., v. 81, p. 149-159, 2009.

THATJE, S. Organismal biology joints(?) climate research: the example of ENSO. Helgol. Mar. Res., v. 62, p. 1-3, 2008 .

THIEL, R.; POTTER, I. C. The ichtyofaunal composition of the Elbe Estuary: an analysis in space and time. Mar. Biol., v. 138, p. 603-616, 2001.

VALESINI, F. J.; POTTER, I. C.; PLATELL, M. E.; HYNDES, G. A. Ichthyofaunas of a temperate estuary and adjacent marine embayment. Implications regarding choice of nursery area influence of environmental changes. Mar. Biol., v. 128, p. 317-328, 1997.

VEIGA, P.; VIEIRA, L.; BEXIGA, C.; SÁ, R.; ERZINI, K.Structure and temporal variations of fish assemblages of the Castro Marim salt marsh, southern Portugal. Estuar. coast. Shelf Sci., v. 70, p. 27-38, 2006.

VIEIRA, J. P. Juvenile mullets (Pisces: Mugilidae) in the Estuary of Lagoa dos Patos, RS, Brazil. Copeia, v. 2, p. 409-418, 1991.

VIEIRA, J. P.; MUSICK, J. A. Fish fauna composition in warm temperate and tropical estuaries of western Atlantic. Atlântica, v. 16, p. 31-53, 1994.

VIZZIANO, D.; SAONA, G.; FRANCO, J.; NAGY, G. Environmental characterization of the spawning area of the white croaker Micropogonias furnieri in the frontal zone of the Río de la Plata. In: VIZZIANO, D.; PUIG, P.; MESONES, C.; NAGY, G. J. (Ed.). The Río de la Plata. Research to manage the environment, fish resources and the fishery in the saline Front. Ecoplata Program, Montevideo, Uruguay. 2001. p. 113-124.

VORWERK, P. D.; WHITFIELD, A. K.; COWLEY, P. D.; PATERSON, A. W. The Influence of Selected Environmental Variables on Fish Assemblage Structure in a Range of Southeast African Estuaries. Environ. Biol. Fish., v. 66, p. 237-247, 2003.

WHITFIELD, A. K. Ichthyofaunal assemblages in estuaries: A South African case study. Revs Fish Biol. Fish. Kluwer Academic Publishers. Printed in the Netherlands. v. 9, p. 151-186, 1999. (Printed in the Netherlands). 
WHITFIELD, A. K.; HARRISON, T. D. River flow and fish abundance in a South African estuary. J. Fish Biol., v. 62, p. 1467-1472, 2003.

ZUUR, A. F.; IENO, E. N.; SMITH, G. M. Analysing ecological Data. New York, NY: Springer, 2007.

(Manuscript received 01 October 2009; revised 14 April 2010; accepted 20 May 2010) 